\title{
Latent gender inequalities in the well-being of physicians according to payment method for practicing medicine: a cross-sectional study
}

\author{
J uan Nicolás Peña-Sánchez, Rein Lepnurm, Silvia Bermedo-Carrasco \\ School of Public Health, University of Saskatchewan, Saskatoon, SK, Canada
}

Correspondence: Juan Nicolás Peña-Sánchez. Address: School of Public Health, University of Saskatchewan, 107 Wiggins Road, Saskatoon, SK., S7N 5E5, Canada. E-mail: juan.nicolas.ps@usask.ca

Received: March 15, 2013

Accepted: April 2, 2013

Online Published: April 19, 2013

DOI : $10.5430 /$ jha.v2n4p7

URL: http://dx.doi.org/10.5430/jha.v2n4p7

\section{Abstract}

Background: Female physicians face extra challenges in their career development and tend to choose salary or other forms of alternative payment plans (APP). Fee-for-service (FFS) and APP may affect the well-being of female and male physicians differently. Three measures of well-being are: levels of career satisfaction, professional equity, and daily distress. The objectives are to identify differences in the levels of career satisfaction, fulfillment-recognition equity, and daily distress of physicians by gender and payment method, and to assess interactions between these two factors.

Methods: A cross-sectional study was conducted in 2011 with physicians practicing in the Saskatoon Health Region, Saskatchewan, Canada. Resident physicians were excluded from the study. Eligible physicians completed a survey, assessing levels of daily distress, fulfillment-recognition equity, and career satisfaction as dependent variables. A multivariate analysis of variance (MANOVA), using the Wilks' Lambda criterion, was conducted to study differences among the dependent variables by remuneration method and gender. Multiple comparisons were performed as post-hoc tests.

Results: Nearly half (382) of the 794 eligible physicians completed the questionnaire; $37.2 \%$ were female. Half were remunerated by FFS, a quarter by APP, and the remainder by blended forms. Career satisfaction and fulfillmentrecognition equity were positively correlated to each other and daily distress was negatively correlated with both. According to the MANOVA results, the dependent variables were affected by gender but not by payment method, and there was no evidence of an interaction effect between payment method and gender. Women reported lower levels of career satisfaction ( $p=0.01)$ and fulfillment-recognition equity $(p=0.01)$, and higher levels of daily distress $(p=0.03)$.

Conclusion: Female physicians reported poorer well-being than male physicians. In contrast, no differences in the well-being were found among physicians paid by APP, blended methods, and FFS schemes. Further cross-national studies are recommended to study potential effects of APP on the identified gender inequalities.

\section{Key words}

Physicians, Well-being, Gender, Career satisfaction, Professional equity, Distress, Payment, Fee-for-service, Alternative payment plans 


\section{Introduction}

The correlation between the well-being of physicians and the quality of health care has been recognized as a relevant association that requires further comprehension, awareness, and interventions ${ }^{[1,2]}$. Physicians' wellness indicators should be incorporated into the evaluation of health care systems ${ }^{[3]}$ and gain the attention of policy and decision makers. Boundaries between work and personal spheres are essential in promoting work-life balance among physicians ${ }^{[4]}$, but these limits are difficult to create, especially for female physicians ${ }^{[5,6]}$. The proportion of female physicians has increased considerably during the last 30 years, especially among family physicians ${ }^{[7]}$. Conflicts between work and home play significant roles in burnout, and the predictors of burnout differ by gender, with the stressors of exhaustion and disengagement stronger among women ${ }^{[8]}$. A study of physicians in Western Canada examined interactions among work-to-family conflicts by gender and parental status, finding a considerable percentage of physicians who are mothers reporting high levels of work-to-family conflicts ${ }^{[9]}$.

Another conflict for female physicians is that they perceive obstacles in their career development which negatively affect their career satisfaction. Female medical school faculty perceive gender discrimination in promotions, allocations of space, access to administrative staff, and the assignment of graduate students ${ }^{[6]}$. There is evidence that female specialists are paid slightly less in comparison to male physicians ${ }^{[10]}$. In addition, it has been reported that new cohorts of female physicians tend to choose alternative payment methods ${ }^{[11]}$ rather than the traditional fee-for-service (FFS) schemes.

FFS has been blamed for escalating costs of the health care system, accounting for more than half the average annual growth of physician spending in Canada ${ }^{[12]}$, and for generating more but briefer patient encounters, affecting quality of care provided and satisfaction of physicians at the primary care level ${ }^{[13]}$. Most Canadian physicians continue to be paid by FFS, but during the last decade alternative payment plans (APP), such as salary, capitation, sessional or blended forms, have been gaining popularity, increasing from $10.6 \%$ in 2000 to $26.8 \%$ of all payments for physicians in $2010^{[14]}$. Despite this transformation in payment systems, available evidence does not explain the impact of APP on the satisfaction of physicians, and the shift from FFS to APP can be considered a "philosophical change" which might modify clinical and personal priorities of practitioners ${ }^{[15]}$. Therefore, it is important to study the effects of APP, FFS, or blended payment systems on career satisfaction and professional equity, given that these two concepts are aspects of motivation ${ }^{[16]}$ : career satisfaction is a longitudinal perception of outcomes evaluating both higher- and lower-order motivational needs ${ }^{[17]}$; and professional equity is a short term process-oriented perception, evaluating the balance between contributions made and rewards received ${ }^{[18]}$. In addition, since stress affects satisfaction and rewards, levels of daily distress need to be concurrently measured when studying well-being of physicians and payment methods.

Several studies have analyzed the impact of payment methods on quantity and quality of health services ${ }^{[19]}$, but differences in the levels of career satisfaction, fulfillment-recognition rewards, and daily distress of physicians by payment method have not been explored. In addition, studies about factors affecting the well-being of physicians need to consider gender differences ${ }^{[20]}$. The objectives of this paper are to identify differences in the levels of career satisfaction, fulfillment-recognition rewards, and daily distress of physicians by gender and payment method (FFS, APP, and blended forms); and to assess interactions between gender and payment method on the three measures of physicians' well-being.

\section{Subjects and Methods}

A cross-sectional study was conducted in 2011, including all physicians practicing in rural and urban areas of the Saskatoon Health Region (SHR). The SHR is the largest health region in Saskatchewan (SK), Canada, providing health care for about 318,000 people (30\% of the province population), and encompasses rural and urban areas (including six First Nations reserves). It is a referral center of specialized care for SK and an academic healthcare organization. The Region includes 10 hospitals, with three tertiary hospitals in the Saskatoon city ${ }^{[21]}$. Medical doctors registered in the list of practitioners of the SHR (850 by May 2011) were considered as the sample frame. Eligible physicians to participate in the 
study were those practicing in the SHR as a health care provider (inclusion criterion). Physicians in a residency program, retired, or on a leave of absence were excluded from the study (exclusion criteria). This study received ethics approval from the Behavior Research Ethics Board of the University of Saskatchewan, and Operational Approval from the SHR.

Eligible physicians were sent a questionnaire and a cover letter, explaining the nature and importance of the study and inviting them to participate either by post or on-line, using recommendations from the Tailored Dillman Approach ${ }^{\text {[22] }}$. Physicians who did not return their questionnaires were contacted one and two months after the first mail-out by post, receiving a letter highlighting the importance of their participation in the study, a copy of the questionnaire booklet, and a pre-stamped envelope; also, three reminders were sent by e-mail. Four months after the first contact, non-participant physicians received a one page non-response survey to check for response bias. The questionnaire asked about current remuneration method (pure FFS, pure APP, or blended methods), career satisfaction, professional equity, daily distress, and demographic factors.

\subsection{Measures}

The measure of career satisfaction contained inherent and performance dimensions to capture satisfaction with higher-order needs, and personal and professional dimensions to capture satisfaction of lower-order needs ${ }^{[17]}$. The measure has four items for each of the four dimensions, all scored on six-point scales, from "very dissatisfied" to "very satisfied”. Mean levels of overall career satisfaction were computed for the 16-item scale, scored from 1.00 to 6.00.

Professional equity was measured in three dimensions: fulfillment (five items), financial (five items), and recognition (five items) rewards for practicing medicine ${ }^{[18]}$. All the items scored on six-point Likert scales. For this study, the dimensions of fulfillment and recognition equity were combined. The scale was scored from 1.00 to 6.00 .

The distress experienced by physicians in their daily practice was measured in two dimensions: fatigue and reaction ${ }^{[23]}$. All items scored on seven-point scales, from "Never" to "Daily". The mean levels of distress were also computed for the 16-item scale, scoring from 1.00 to 7.00, identifying job strain at lower levels and risk of burnout at higher levels.

The measures of career satisfaction ${ }^{[17]}$, professional equity ${ }^{[18]}$ and daily distress ${ }^{[23]}$ were validated in a Canadian cross-national sample among different medical specialties.

\subsection{Statistical analysis}

To study differences in the levels of career satisfaction, fulfillment-recognition rewards, and daily distress among physicians paid by the three remuneration methods (FFS, blended, and APP) and gender, a multivariate analysis of variances (MANOVA) was conducted using the general linear model ${ }^{[24]}$ of $\operatorname{SPSS}^{\circledR} 20$, and the Wilks' Lambda criterion was considered. Multiple comparisons were performed as post-hoc tests.

\section{Results}

Of the 794 eligible physicians in the SHR, a total of 382 completed the questionnaire (response rate=48.1\%). The majority of the questionnaires, two thirds, were completed on paper and the other third was submitted on-line. In the sample, 37.2\% $(\mathrm{n}=142)$ were female physicians and $62.8 \%(\mathrm{n}=240)$ were male. Slightly less than half $(45.3 \%)$ of the physicians were remunerated by FFS, $24.6 \%$ by APP, and $30.1 \%$ were under mixed models. Table 1 presents the distribution of payment methods by gender. The reliability for the measures of well-being (career satisfaction, fulfillment-recognition equity, and daily distress scales) was very high (Table 2). The three dependent variables were found to be moderately correlated: career satisfaction and fulfillment-recognition equity $(r=0.66, p<0.001)$; career satisfaction and daily distress $(r=-0.53$, $p<0.001)$; and, fulfillment-recognition equity and daily distress $(r=-0.40, p<0.001)$. 
Table 1. Payment methods and demographics by gender

\begin{tabular}{llll}
\hline & All physicians & Women & Men \\
$\mathbf{n = 3 8 2}$ & $\mathbf{1 4 2}(\mathbf{3 7 . 2 \% )}$ & $\mathbf{2 4 0} \mathbf{( 6 2 . 8 \% )}$ \\
\hline Payment method & $173(45.3 \%)$ & $59(41.5 \%)$ & $114(47.5 \%)$ \\
FFS & $115(30.1 \%)$ & $44(31 \%)$ & $71(29.6 \%)$ \\
Blended & $94(24.6 \%)$ & $39(27.5 \%)$ & $55(22.9 \%)$ \\
APP & $49.04(11.4)$ & $46.8(10.1) *$ & $50.4(11.9) *$ \\
Age in years-old - mean (SD) & & & $12(5.1 \%)$ \\
Marital status & $26(6.9 \%)$ & $14(9.9 \%)$ & $217(91.6 \%)$ \\
Single & $335(88.4 \%)$ & $118(83.1 \%)$ & $5(2.1 \%)$ \\
Married/common law & $11(2.9 \%)$ & $6(4.2 \%)$ & $3(1.3 \%)$ \\
Separated/divorced & $7(1.8 \%)$ & $3(2.1 \%)$ & - \\
Widowed/other & $3(0.8 \%)$ & $3(0.7 \%)$ & $79(32.9 \%)$ \\
Missing data & & & $73(34.4 \%)$ \\
Specialty group & $136(35.6 \%)$ & $57(40.1 \%)$ & $70(29.6 \%)$ \\
Family/general practitioners & $120(31.4 \%)$ & $47(33.1 \%)$ & $17(7.1 \%)$ \\
Medical specialties & $99(25.9 \%)$ & $28(19.7 \%)$ & $19.9(12.8) * *$ \\
Surgical specialties & $27(7.1 \%)$ & $10(7 \%)$ & $16(11) * *$ \\
Laboratory and medical images & $18.5(12.3)$ & & \\
Years in practice - mean (SD) & & & \\
\hline
\end{tabular}

*t(328.9) $=-3.14, p=0.002 ; * * t(326.3)=-3.15, p=0.002 ; \chi 2$ Tests were not significant, $p$-values $>0.05$.

The MANOVA test (Wilks' Lambda criterion) identified that the three dependent variables were significantly affected by gender, $\mathrm{F}(3,374)=2.83, p=0.04$, but not by the payment method, $\mathrm{F}(6,748)=1.02, p=0.41$; moreover, there was no evidence of an interaction effect between payment method and gender, $\mathrm{F}(6,748)=1.2, p=0.3$. In addition, the box's $\mathrm{M}$ was 33.84, $p=0.32$, holding the assumption of homogeneity of variance-covariance matrices.

Table 2. Career satisfaction, professional fulfillment-recognition equity, and daily distress of physicians by gender and payment method

\begin{tabular}{|c|c|c|c|c|c|c|c|c|c|c|}
\hline \multirow[b]{2}{*}{$\begin{array}{l}\text { Dependent } \\
\text { variables }\end{array}$} & \multirow[b]{2}{*}{$a$} & \multirow[b]{2}{*}{$\begin{array}{l}n=382 \\
\text { Mean } \\
(\mathrm{SD})\end{array}$} & \multicolumn{3}{|l|}{ Gender } & \multicolumn{4}{|c|}{ Payment Method } & \multirow{2}{*}{$\begin{array}{l}\text { Interaction } \\
\text { F-value }\end{array}$} \\
\hline & & & $\begin{array}{l}\text { Women } \\
\text { Mean } \\
\text { (SD) }\end{array}$ & $\begin{array}{l}\text { Men } \\
\text { Mean } \\
\text { (SD) }\end{array}$ & F-value & $\begin{array}{l}\text { FFS } \\
\text { Mean } \\
(\mathrm{SD}) \\
\end{array}$ & $\begin{array}{l}\text { Blended } \\
\text { Mean } \\
\text { (SD) }\end{array}$ & $\begin{array}{l}\text { APP } \\
\text { Mean } \\
\text { (SD) }\end{array}$ & F-value & \\
\hline $\begin{array}{l}\text { Career } \\
\text { satisfaction }\end{array}$ & 0.84 & $\begin{array}{l}4.23 \\
(0.68)\end{array}$ & $\begin{array}{l}4.14 \\
(0.57)\end{array}$ & $\begin{array}{l}4.27 \\
(0.63)\end{array}$ & $60.7 * *$ & $\begin{array}{l}4.19 \\
(0.63)\end{array}$ & $\begin{array}{l}4.26 \\
(0.63)\end{array}$ & $\begin{array}{l}4.25 \\
(0.63)\end{array}$ & 0.15 & 1.61 \\
\hline $\begin{array}{l}\text { Fulfillment } \\
\text { recognition } \\
\text { equity }\end{array}$ & 0.86 & $\begin{array}{l}4.24 \\
(0.72)\end{array}$ & $\begin{array}{l}4.15 \\
(0.71)\end{array}$ & $\begin{array}{l}4.29 \\
(0.72)\end{array}$ & $6.18^{* *}$ & $\begin{array}{l}4.14 \\
(0.73)\end{array}$ & $\begin{array}{l}4.29 \\
(0.71)\end{array}$ & $\begin{array}{l}4.34 \\
(0.69)\end{array}$ & 1.70 & $3.41^{+}$ \\
\hline $\begin{array}{l}\text { Daily } \\
\text { distress }\end{array}$ & 0.87 & $\begin{array}{l}3.31 \\
(0.89)\end{array}$ & $\begin{array}{l}3.43 \\
(0.84)\end{array}$ & $\begin{array}{l}3.24 \\
(0.92)\end{array}$ & $5.07^{*}$ & $\begin{array}{l}3.34 \\
(0.95)\end{array}$ & $\begin{array}{l}3.22 \\
(0.86)\end{array}$ & $\begin{array}{l}3.36 \\
(0.81)\end{array}$ & 0.74 & 0.96 \\
\hline
\end{tabular}

a :Cronbach's Alpha
${ }^{*} p=0.03 ; * * p=0.01 ;+p=0.02$

Significant differences in the mean levels of career satisfaction, fulfillment-recognition equity, and daily distress were identified between female and male physicians (Table 2). Women scored lower levels of career satisfaction, $\mathrm{F}(1,376)=6.07, p=0.01$, and fulfillment-recognition equity than men, $\mathrm{F}(1,376)=6.18, p=0.01$, and female physicians referred higher levels of daily distress compared to male physicians, $\mathrm{F}(1,376)=5.07, p=0.03$. In contrast, no significant differences were identified by remuneration method. However, an interaction effect between gender and payment method on the mean levels of fulfillment-recognition equity was significant, $\mathrm{F}(2,376)=3.41, p=0.03$, suggesting that the 
importance of intrinsic rewards is stronger among men with APP (Table 3). Caution in the interpretation is warranted, since this interaction could be a type I error due to the multiple comparisons performed. Therefore, the mean levels are shown with error bars for the three outcome variables (Figure 1).

Table 3. Mean levels of physician's professional equity, daily distress, and career satisfaction by payment method and gender

\begin{tabular}{|c|c|c|c|c|}
\hline Measurement & Payment method & Gender & $\mathbf{n}$ & Mean (SD) \\
\hline \multirow{6}{*}{ Career Satisfaction } & \multirow{2}{*}{ FFS } & female & 59 & $4.19(0.57)$ \\
\hline & & male & 114 & $4.20(0.66)$ \\
\hline & \multirow{2}{*}{ Blended } & female & 44 & $4.13(0.61)$ \\
\hline & & male & 71 & $4.34(0.64)$ \\
\hline & \multirow{2}{*}{ APP } & female & 39 & $4.09(0.54)$ \\
\hline & & male & 55 & $4.36(0.52)$ \\
\hline \multirow{6}{*}{ Fulfillment-recognition equity } & \multirow{2}{*}{ FFS } & female & 59 & $4.18(0.66)$ \\
\hline & & male & 114 & $4.12(0.76)^{\mathrm{T}} *$ \\
\hline & \multirow{2}{*}{ Blended } & female & 44 & $4.14(0.73)$ \\
\hline & & male & 71 & $4.39(0.69)^{\mathrm{T}}$ \\
\hline & \multirow{2}{*}{ APP } & female & 39 & $4.11(0.77)^{+}$ \\
\hline & & male & 55 & $4.51(0.58)^{+} *$ \\
\hline \multirow{6}{*}{ Daily distress } & \multirow{2}{*}{ FFS } & female & 59 & $3.38(0.91)$ \\
\hline & & male & 114 & $3.32(0.98)$ \\
\hline & \multirow{2}{*}{ Blended } & female & 44 & $3.35(0.88)$ \\
\hline & & male & 71 & $3.15(0.85)$ \\
\hline & \multirow{2}{*}{ APP } & female & 39 & $3.58(0.68)$ \\
\hline & & male & 55 & $3.20(0.85)$ \\
\hline
\end{tabular}

Significant pair-wise comparisons

${ }^{*}=0.003 ;{ }^{+}=0.008 ;{ }^{\mathrm{T}} p=0.03$

\section{Discussion}

This study found differences in the reported well-being between male and female physicians. There are inequalities in the perceptions of career satisfaction, professional equity and daily distress levels between female and male physicians that need attention. Female physicians, in comparison to men, report earning less ${ }^{[10,25]}$, experience less control over patient load and more time pressure to see their patients and, simultaneously, state that they see more patients with psychosocial problems ${ }^{[25,26]}$. Further, female physicians experience additional stressors, like discrimination, lack of role models and support, and the challenge of balancing career and family spheres. Medical students have experiences of gender discrimination which result in resignation, influencing professional identity and choice of specialty among new female physicians ${ }^{[27]}$. Although the proportion of females among new cohorts ${ }^{[7]}$-including female professors — is increasing, they are still under-represented among positions in medical leadership ${ }^{[28]}$. Physicians who are mothers have more work-to-family conflicts compared to father physicians and to male or female physicians who are not parents ${ }^{[9]}$. These are critical factors that directly involve female physicians, new cohorts and current practitioners, as well as policy makers, since strategies to eliminate gender inequalities in the well-being of physicians are still required. In addition, these are facts that need to be considered when selecting and designing payment methods for practicing medicine.

When comparing APP, blended methods, and FFS, it is positive that no significant differences were identified in the levels of daily distress, fulfillment-recognition equity and career satisfaction of physicians. In fact, since a lack of professional 
and clinical autonomy is associated with career dissatisfaction ${ }^{[29]}$ and poor professional rewards ${ }^{[30]}$, the findings indicate that alternative payment schemes, both blended forms and pure APP, do not threaten physicians' clinical autonomy. Moreover, the intrinsic and unalterable tensions of practicing medicine are not affected by alternative payment methods.

Figure 1. Error bars of the three dependent variables by payment methods and gender

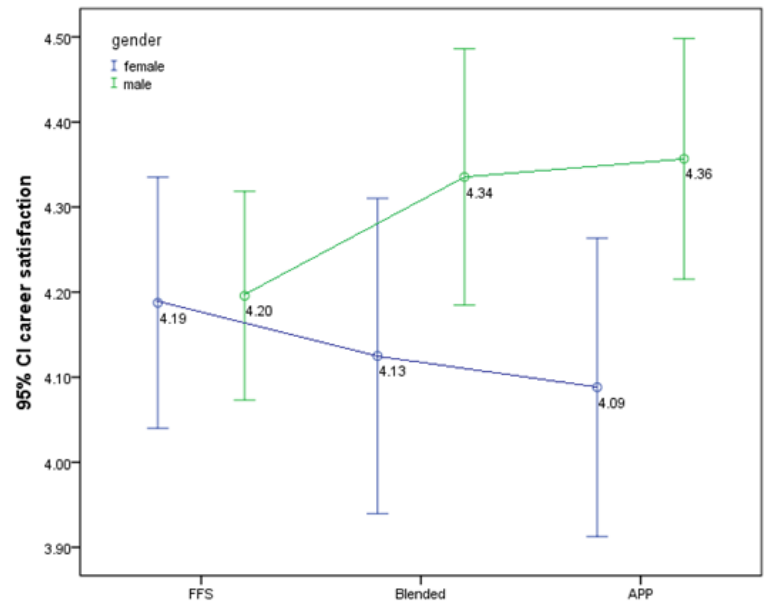

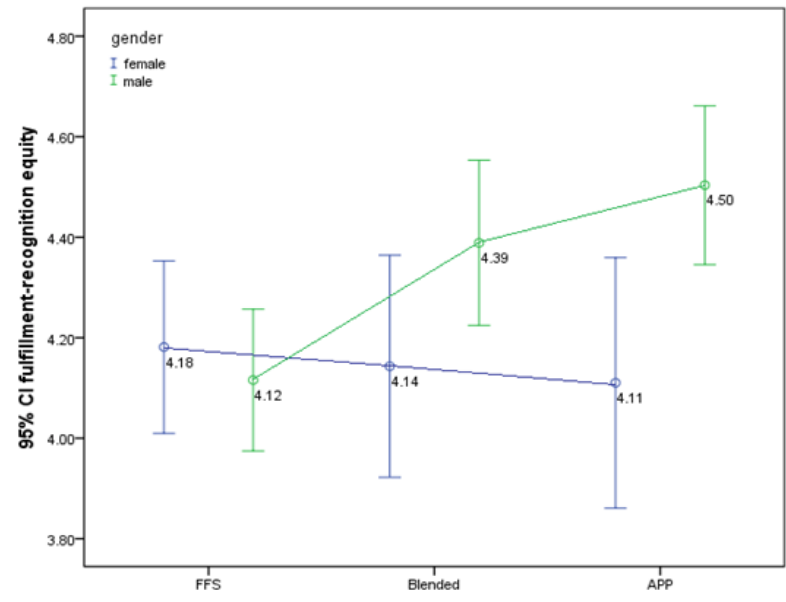

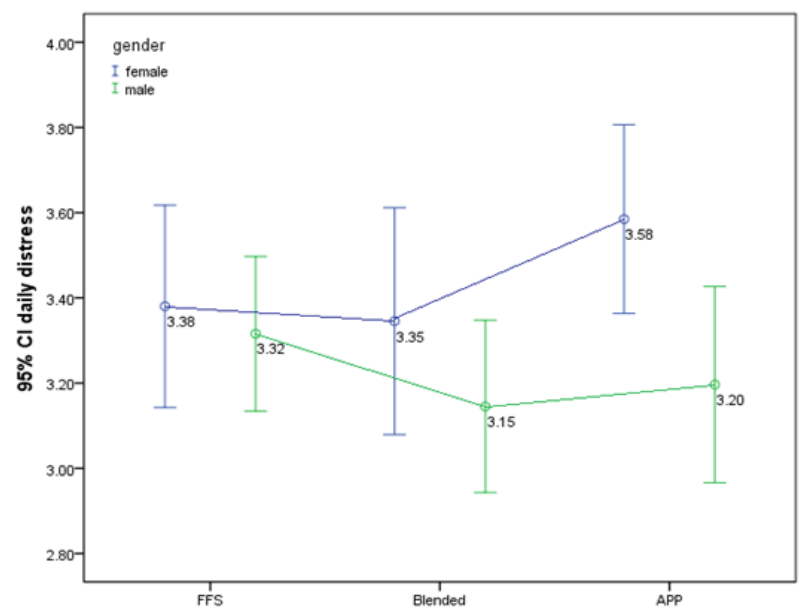

Female physicians give more importance to issues such as control of work schedule and environment, and recognition for their work ${ }^{[25]}$. Since female physicians report higher percentage of complex patients ${ }^{[25]}$, less control on daily aspects of practice ${ }^{[26]}$, extra challenges to achieve work-life balance ${ }^{[5,6,9]}$ and professional development ${ }^{[6,10]}$, alternative payment schemes should acknowledge these factors, providing the necessary flexibility to enhance their motivation.

Given that this was a cross-sectional study, findings must be considered as associations. However, results can be extrapolated to physicians practicing in the SHR and the Regina Qu'Appelle Health Region and, with caution, to other similar regions across Canada. In comparison with other surveys among physicians, the response rate of this study is adequate; especially because response bias was tested and found to be negligible. Finally, sufficient numbers of specialists among the three payment methods were limited. National studies with bigger and stratified samples are needed to further explore the well-being of physicians.

\section{Conclusions}

Female physicians reported poorer levels of career satisfaction and professional equity; and higher levels of daily distress, in comparison to male physicians. These are findings that evidence a lack of gender equity in the well-being of 
practitioners which needs to be addressed. In contrast, pure APP and blended payment methods did not show differences in the well-being indicators when compared to traditional FFS; a finding that could promote APP for physicians. APPs have been recommended to engage physicians in research and academic duties, as well as administrative responsibilities ${ }^{\text {[31] }}$, along with providing incentives for health promotion and preventive services ${ }^{[32]}$; while FFS has been described as adequate to reward high quantities of clinical care ${ }^{[33]}$. Finally, it is recommended that the potential interaction effects of APP and gender be explored in further studies with stratified samples across provinces.

\section{Acknowledgements}

The authors want to thank to the physicians who participated in the study, as well as to the Medical Affairs Office, Saskatoon Health Region, and its staff for their support. We want to show appreciation to the invaluable support of all members of the MERCURi Research Group of the School of Public Health, University of Saskatchewan, who contributed to the development of our research. Finally, this study was financed by the MERCURi Group; and the doctoral studies of two authors were partially financed by the WRTC training program.

\section{Competing interests}

The authors declare that they have no competing interests.

\section{References}

[1] Williams E, Skinner A. Outcomes of physician job satisfaction: a narrative review, implications, and directions for future research. Health Care Manage Rev. 2003; 28: 119-40. http://dx.doi.org/10.1097/00004010-200304000-00004

[2] Wallace JE, Lemaire J. Physician well-being and quality of patient care: an exploratory study of the missing link. Psychol Health Med. 2009; 14: 545-52. PMid:19844833 http://dx.doi.org/10.1080/13548500903012871

[3] Wallace JE, Lemaire JB, Ghali WA. Physician wellness: a missing quality indicator. Lancet. 2009; 374: $1714-21$. http://dx.doi.org/10.1016/S0140-6736(09)61424-0

[4] Shanafelt TD, West CP, Poland GA, LaRusso NF, Menaker R, Bahn RS. Principles to promote physician satisfaction and work-life balance. Minn Med. 2008; 91: 41-3. PMid:19902622

[5] Verlander G. Female physicians: balancing career and family. Acad Psychiatry. 2004; 28: 331-6. PMid:15673831 http://dx.doi.org/10.1176/appi.ap.28.4.331

[6] Shollen SL, Bland CJ, Finstad DA, Taylor AL. Organizational climate and family life: how these factors affect the status of women faculty at one medical school. Acad Med. 2009; 84: 87-94. PMid:19116483 http://dx.doi.org/10.1097/ACM.0b013e3181900edf

[7] Canadian Institute for Health Information (CIHI). Supply, Distribution and Migration of Canadian Physicians, 2010 [Internet]. CIHI 2011. Available from: https://secure.cihi.ca/estore/productFamily.htm?locale=en\&pf=PFC1680

[8] Langballe EM, Innstrand ST, Aasland OG, Falkum E. The predictive value of individual factors, work-related factors, and workhome interaction on burnout in female and male physicians: a longitudinal study. Stress and Health. 2011; $27:$ 73-87. http://dx.doi.org/10.1002/smi.1321

[9] Wallace JE, Lemaire J. On physician wellbeing-you'll get by with a little help from your friends. Soc Sci Med. 2007; 64: $2565-77$. PMid:17451854 http://dx.doi.org/10.1016/j.socscimed.2007.03.016

[10] Leigh JP, Tancredi D, Jerant A, Kravitz RL. Physician wages across specialties: informing the physician reimbursement debate. Arch Intern Med. 2010; 170: 1728-34. PMid:20975019 http://dx.doi.org/10.1001/archinternmed.2010.350

[11] Canadian Institute for Health Information (CIHI). Profiling Physicians by Payment Program: A Closer Look at Three Provinces [Internet]. CIHI 2010. Available from: https://secure.cihi.ca/estore/productFamily.htm?pf=PFC1400.

[12] Canadian Institute for Health Information (CIHI). Health Care Cost Drivers: The Facts [Internet]. CIHI 2011. Available from: https://secure.cihi.ca/estore/productFamily.htm?locale=en\&pf=PFC1672.

[13] Berenson RA, Rich EC. US approaches to physician payment: the deconstruction of primary care. J Gen Intern Med. 2010; 25: 613-8. PMid:20467910 http://dx.doi.org/10.1007/s11606-010-1295-z

[14] National Physician Database, 2009-2010 Data Release [Internet]. Canadian Institute for Health Information, 2011. Available from: https://secure.cihi.ca/estore/productFamily.htm?pf=PFC1678\&lang=en\&media=0

[15] Elit L, Cosby J, Ontario GOGi. Does shifting a physician payment system shift physician priorities? A multi-site evaluation of an alternative payment plan (APP) for gynecologic oncologists in Ontario. Eur J Gynaecol Oncol. 2006; 27: 375-8. 
[16] Borkowski N. Organizational Behavior, Theory, and Design in Health Care: Jones and Bartlett Publishers, 2008.

[17] Lepnurm R, Danielson D, Dobson R, Keegan D. Cornerstones of career satisfaction in medicine. Can J Psychiatry. 2006; 51: 512-22. PMid:16933588

[18] Dobson R, Lepnurm R, Struening E. Developing a scale for measuring professional equity among Canadian physicians. Soc Sci Med. 2005; 61: 263-6. PMid:15893043 http://dx.doi.org/10.1016/j.socscimed.2004.11.053

[19] Wranik DW, Durier-Copp M. Physician remuneration methods for family physicians in Canada: expected outcomes and lessons learned. Health Care Anal. 2010; 18: 35-59. PMid:19172400 http://dx.doi.org/10.1007/s10728-008-0105-9

[20] Shanafelt TD, Sloan JA, Habermann TM. The well-being of physicians. Am J Med. 2003; 114: 513-9. http://dx.doi.org/10.1016/S0002-9343(03)00117-7

[21] Annual Report 2011-2012 Saskatoon Health Region. Saskatoon Health Region, 2012 [Internet]. Available from: http://www.saskatoonhealthregion.ca/about_us/documents/shr_annual_report_2011_12.pdf

[22] Dillman DA, Smyth JD, Christian LM. Internet, mail, and mixed-mode surveys: the tailored design method. Hoboken, N.J: Wiley \& Sons, 2009.

[23] Lepnurm R, Lockhart WS, Keegan D. A measure of daily distress in practising medicine. Can J Psychiatry. 2009 ; 54: 170-80.

[24] Tabachnick BG, Fidell LS. Using Multivariate Statistics. 5th ed ed. Boston: Pearson/Allyn \& Baco, 2007.

[25] McMurray JE, Linzer M, Konrad TR, Douglas J, Shugerman R, Nelson K. The work lives of women physicians. J Gen Intern Med. 2000; 15: 372-80. PMid:10886471

[26] Brown S, Gunderman RB. Viewpoint: enhancing the professional fulfillment of physicians. Acad Med. 2006 ; 81: 577-82. PMid:16728814 http://dx.doi.org/10.1097/01.ACM.0000225224.27776.0d

[27] Babaria P, Abedin S, Berg D, Nunez-Smith M. "I'm too used to it": a longitudinal qualitative study of third year female medical students' experiences of gendered encounters in medical education. Soc Sci Med. 2012; 74: 1013-20. PMid:22341202 http://dx.doi.org/10.1016/j.socscimed.2011.11.043

[28] Robinson GE. Stresses on women physicians: consequences and coping techniques. Depress Anxiety. 2003; 17: 180-9. PMid:12768652 http://dx.doi.org/10.1002/da.10069

[29] Stoddard J, Hargraves J, Reed M, Vratil A. Managed care, professional autonomy, and income: effects on physician career satisfaction. J Gen Intern Med. 2001; 16: 675-84. PMid:11679035 http://dx.doi.org/10.1111/j.1525-1497.2001.01206.x

[30] Siegrist J, Shackelton R, Link C, Marceau L, von dem Knesebeck O, McKinlay J. Work stress of primary care physicians in the US, UK and German health care systems. Soc Sci Med. 2010; 71: 298-304. PMid:20494505 http://dx.doi.org/10.1016/j.socscimed.2010.03.043

[31] Sarma S, Devlin RA, Belhadji B, Thind A. Does the way physicians are paid influence the way they practice? The case of Canadian family physicians' work activity. Health Policy. 2010; 98: 203-17. PMid:20637519 http://dx.doi.org/10.1016/j.healthpol.2010.06.019

[32] Gosden T, Forland F, Kristiansen IS, Sutton M, Leese B, Giuffrida A, et al. Capitation, salary, fee-for-service and mixed systems of payment: effects on the behaviour of primary care physicians. Cochrane Database Syst Rev 2000(3):CD002215. PMid:10908531

[33] Devlin RA, Sarma S. Do physician remuneration schemes matter? The case of Canadian family physicians. J Health Econ. 2008; 27: 1168-81. PMid:18586341 http://dx.doi.org/10.1016/j.jhealeco.2008.05.006 